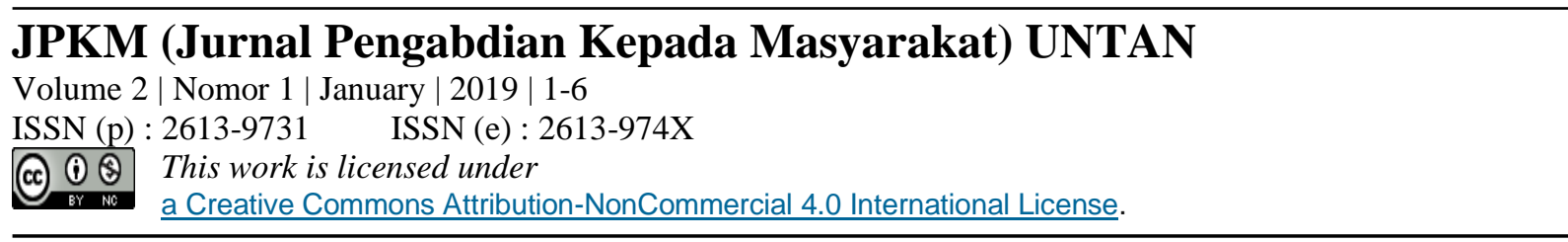

\title{
The Training of Portfolio-Based Learning Model to Develop The Democracy Value and The Students' Critical Thinking Skill
}

\author{
Sulistyarini, Bambang Budi Utomo, Rum Rosyid, Thomy Sastra Atmaja \\ Universitas Tanjungpura, Pontianak, Indonesia
}

Email: purnamag5@yahoo.go.id

\author{
Keywords : \\ Portfolio Learning Model, \\ Critical Thinking, Pancasila \\ and Civic Education
}

\begin{abstract}
Pancasila and Citizenship Education (PPKn) Learning is a vehicle for democratic education. In the context of international discourse, PPKn learning in Indonesia is still included in the knowing democracy paradigm. While in other countries, it is already in the paradigm of building democracy. For this reason, PPKn learning needs to be facilitated so that it develops from the knowing democracy paradigm towards doing democracy. As a vehicle for the education and development of democratic citizens, the PPKn has three main functions, namely developing civic intelligence, fostering civic responsibility, and encouraging civic participation. The three competencies of citizens are in line with the three main components as a learning estuary for PPKn namely civic knowledge, civic skills and civic dispositions. PPKn learning can ideally equip students with sufficient knowledge and intellectual skills as well as provide practical experience to have competence and be able to participate effectively. For this reason, two things need attention in preparing PPKn learning in class, namely knowledge about learning materials and the use of learning methods/models. One learning model that is suitable to be applied in PPKn learning is portfolio-based because the superiority of this model in its application can develop democratic values and enhance students' critical thinking skills. However, discussions with several teachers obtained information that many of them did not understand the characteristics, advantages, and ways of implementing portfolio-based learning models on PPKn learning so that this model does not get the attention to be applied by teachers in learning PPKn. Community Service Activities were carried out on August 14, 2018, located at Sungai Pinyuh State Middle School 3, Mempawah Regency, and were attended by teachers from the MGMP PPKn SLTP level throughout the District of Mempawah. This community service activity has the goal of increasing teacher knowledge and understanding of planning, implementing, evaluating, and knowing the obstacles faced by teachers in applying portfolio-based PPKn learning to develop democratic values and critical thinking abilities of students. PKM activities carried out in the form/method of
\end{abstract}


socialization. The result of this activity is an increase in the knowledge and understanding of PPKn teachers on the concepts and nature of portfolio learning models, the effectiveness of portfolio learning models to develop democratic values and critical thinking skills of students, the application of portfolio learning models in planning, implementing, and evaluating PPKn learning activities, and regarding various obstacles faced by PPKn teachers in applying the portfolio model.

\section{INTRODUCTION}

Pancasila and Citizenship Education (PPKn) Learning is a vehicle for democratic education. In the context of international discourse, PPKn learning in Indonesia is still included in the knowing democracy paradigm. While in other countries, it is already in the paradigm of building democracy. For this reason, PPKn learning needs to be facilitated so that it develops from the knowing democracy paradigm towards doing democracy.

As a vehicle for the education and development of democratic citizenship, PPKn has three main functions, namely developing civic intelligence, fostering civic responsibility, and encouraging civic participation (civic participation). The three competencies of citizens are in line with the three main components as PPU's learning estuaries, namely civic knowledge, civic skills, and civic dispositions (Branson, 1999: 8).

Based on the learning function and estuary, PPKn learning must be dynamic. Through learning the teacher must help develop the potential and attract the attention of students so that both material understanding and intellectual skills and participatory students are better. In line with this, Donald W. Robinson (Cholisin, 2007: 18) assures that critical thinking skills are essential for the development of citizens to create democratic citizens. Citizens who can think critically must be based on democratic values. It means that democratic citizens can produce thoughts that are accommodating to pluralism/differences or are consistent in the establishment of their thoughts but still respect the thoughts of others.

Characteristics of critical thinking in PPKn as an effort to realize good citizens, who have democratic and responsible personalities, including having the ability to make criticisms in the form of "social criticism" and "social control."

Therefore, PPKn learning can ideally equip students with sufficient knowledge and intellectual skills as well as provide practical experience to have competence and be able to participate effectively. Intellectual skills in PPKn subjects cannot be separated from citizenship material, because to be able to think critically about an issue or issue of citizenship, students, in addition, must have a good understanding of various concepts, backgrounds, and relevant contemporary matters as well must have an intellectual thinking device.

For this reason, two things need attention in preparing PPKn learning in class, namely knowledge about learning materials and the use of learning methods/models. One learning model that is suitable to be applied in PPKn learning is portfolio-based because the superiority of this model in its application can develop democratic values and enhance students' critical thinking skills.

The portfolio-based learning model is an effort made by the teacher in the learning process so that students can express and express themselves as individuals and groups. This ability is obtained through learning experiences. Portfolio-based learning is a learning model that actively engages students in learning. Including involving students in critical thinking and making decisions on contemporary issues to create this model suitable for use in PPKn learning.

Based on the discussion of several PPKn subjects in MGMP PPKn activities where the writer as a resource introduced various learning models that can be applied in PPKn learning, it was found that in learning PPKn it still seemed stiff, less flexible, less dynamic, teachers tended to be more dominant 
with one-way method or one-way traffic and not yet in the direction of multi ways traffic. In addition, students are less critical. From the discussion and presentation of the material, one PPKn teacher said that they did not understand the variety of learning models, especially portfolio-based learning models. Some teachers lack an understanding of the characteristics, advantages, and ways of implementing portfolio-based learning models on PPKn learning so that this model does not get the attention to be applied by teachers in learning PPKn.

Based on the facts mentioned above, this is the reason for the writer's interest to carry out the "Training on the Use of Portfolio Based Learning Models to Develop Democratic Values and Students' Critical Thinking Abilities for PPKn Teachers."

Problem.

Based on the background description above, it can be formulated some problems in community service activities, namely:

1. How is the teacher's knowledge of portfolio-based PPKn learning planning to develop democratic values and students' critical thinking skills?

2. How is the teacher's knowledge of the implementation of portfolio-based PPKn learning to develop democratic values and students' critical thinking skills?

3. How is the teacher's knowledge of portfolio-based PPKn learning assessments to develop democratic values and students' critical thinking skills?

4. How is the teacher's knowledge of the obstacles encountered in applying portfolio-based PPKn learning to develop democratic values and students' critical thinking skills?

Troubleshooting Plan.

This form of community service is the Training of Using Portfolio-Based Learning Models to Develop Democratic Values and Students' Critical Thinking Abilities for Teachers of Pancasila and Citizenship in Mempawah District ". For this reason, the problem-solving framework is as follows:

1. Provide knowledge and understanding to PPKn teachers about the concepts and nature of portfolio learning models.

2. Providing knowledge and understanding to PPKn teachers about the effectiveness of portfolio learning models to develop democratic values and students' critical thinking skills.

3. Providing knowledge and understanding to PPKn teachers about applying portfolio learning models in planning, implementing, and evaluating PPKn learning.

4. Providing knowledge and understanding to PPKn teachers about the obstacles faced in applying the portfolio model in PPKn learning.

Realization of Problem Solving.

Community service activities have been carried out by the team so that the realization of problemsolving as above has also been carried out in the form of:

1. Presenting material to PPKn teachers about the concepts and nature of portfolio learning models.

2. Presenting material to PPKn teachers about the effectiveness of portfolio learning models to develop democratic values and students' critical thinking skills.

3. Presenting material to PPKn teachers on how to apply portfolio learning models in planning, implementing, and evaluating PPKn learning.

4. Presenting material to PPKn teachers about the obstacles encountered in applying the portfolio model in PPKn learning.

Purpose of Community Service.

Based on the background and formulation of the problem above, the purpose of community service is to:

1. Increase teacher knowledge and understanding of learning planning based on PPKn portfolio to develop democratic values and critical thinking skills of students.

2. Increase teacher knowledge and understanding of the implementation of portfolio-based PPKn learning to develop democratic values and students' critical thinking skills.

3. Increase teacher knowledge and understanding of portfolio-based PPKn learning assessments to develop democratic values and students' critical thinking skills. 
4. Increasing the teacher's knowledge and understanding of the obstacles faced in applying portfoliobased PPKn learning to develop democratic values and students' critical thinking skills.

Benefits of Activities.

The benefits of community service activities are as follows:

1. For Schools: Help improves the pedagogical competence of human resources in schools, especially PPKn teachers.

2. For Teachers: Provide teachers with understanding and direct experience of various learning models, especially portfolio learning models in learning Pancasila and Citizenship Education in developing democratic values and students' critical thinking skills.

3. For Students: Help develop democratic values and students' critical thinking skills.

\section{METHOD}

Activity Method.

Community Service Activities are carried out in the form/method of socialization. The implementation of this training activity was held one time. The PKM activity was attended by teachers from the MGMP PPKn SLTP level in all the districts of Mempawah.

Place of Activity.

The place for Community Service Activities is carried out in Mempawah Regency, which is located at Sungai Pinyuh State 3 Middle School (Sungai Pinyuh Middle School 3).

Implementation and Activity Schedule.

The implementation of Community Service activities entitled "Training on the Use of Portfolio-Based Learning Models to Develop Democratic Values and Students' Critical Thinking Ability for Teachers of Pancasila and Citizenship Education in Mempawah District" was held at SMPN 3 Sungai Pinyuh Mempawah Regency on August 14, 2018.

While the schedule of Community Service activities starts from planning to implementation, which is six months of work from May to October 2018.

Media / Socialization Tool.

The media/devices used in this implementation consist of PowerPoint media, image media, and LCD Projector.

\section{RESULTS AND DISCUSSIONS}

The results achieved.

This activity has been carried out well and runs smoothly. The result of this activity is an increase in the knowledge and understanding of PPKn teachers on the concepts and nature of portfolio learning models, the effectiveness of portfolio learning models to develop democratic values and critical thinking skills of students, the application of portfolio learning models in planning, implementing, and evaluating PPKn learning activities, and regarding various obstacles faced by PPKn teachers in applying the portfolio model.

Linkages of Activities.

This community service activity is an implementation of the tri dharma of higher education. This activity was carried out by a team of lecturers of the PPKn Study Program to increase the knowledge and understanding of teachers in applying portfolio-based learning models in the planning, implementation, and evaluation of PPKn learning. 


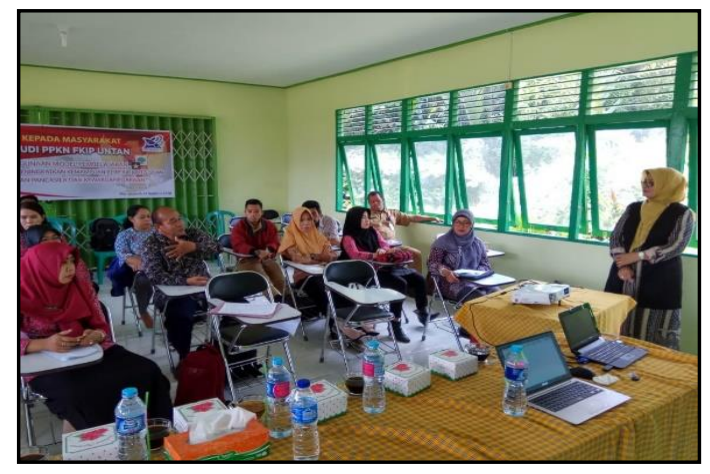

Fig. 1 Submission of Socialization Material

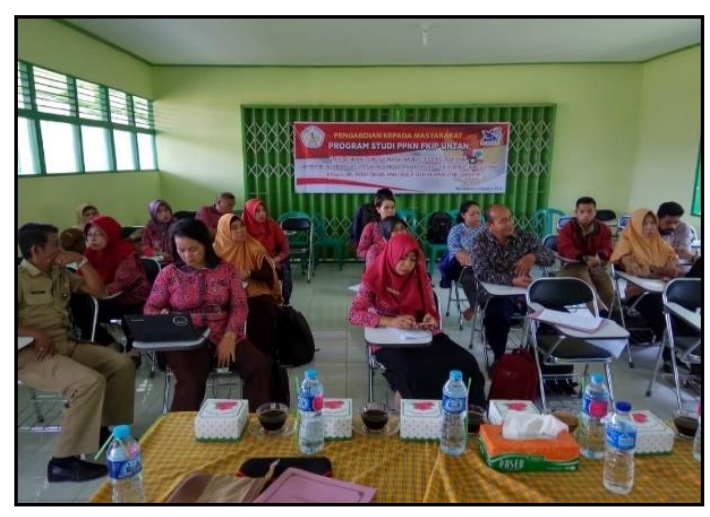

Fig. 2 Classroom Atmosphere During the Socialization Activity

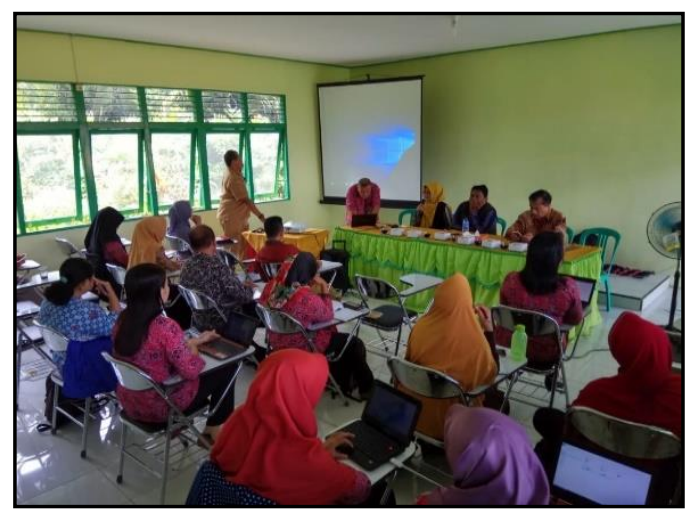

Fig. 3 Question and Answer Session with Speakers

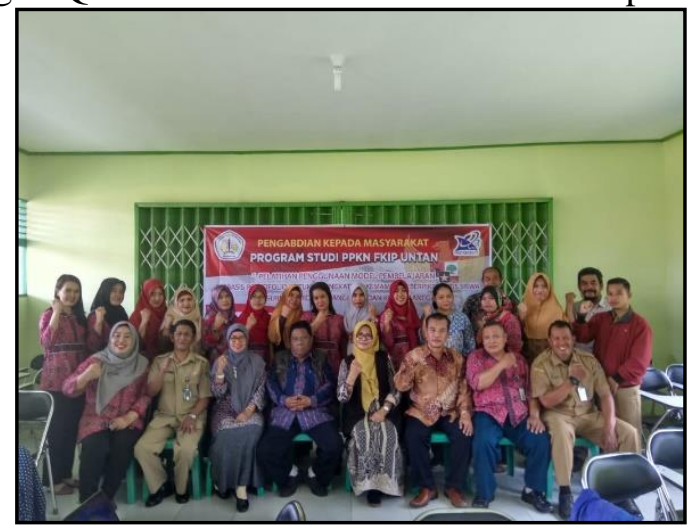

Fig. 4 Group Photos of Presenters and Participants (Teachers) 


\section{CONCLUSION AND SUGGESTION}

A. Conclusions

The conclusions of the Community Service Activities are as follows:

1. That the teacher's knowledge of the planning, implementation, and assessment of PPKn based learning portfolio to develop democratic values and critical thinking skills of students is still relatively low so that the existence of socialization through community service activities is beneficial for teachers' understanding of the issue.

2. That the teacher's knowledge of the constraints faced in applying portfolio-based PPKn learning to develop democratic values and critical thinking skills of students is still relatively low so that the existence of community service activities is beneficial to the teacher's understanding in addressing the obstacles faced and looking for alternative solutions.

B. Suggestions

As for the suggestions in this Community Service activity are the following:

1. PPKn teachers should always consider the use of portfolio-based learning models in their learning activities as an effort to develop democratic values and students' critical thinking skills.

2. Academics (lecturers) should more often provide training in the form of socialization activities to provide understanding to PPKn teachers regarding the use of portfolio-based learning models in their learning activities as an effort to develop democratic values and students' critical thinking skills.

\section{REFERENCES}

Branson, Margaret S. dkk. (1999). Belajar Civic Education dari Amerika. Yogyakarta: Lembaga Kajian Islam dan Sosial (LKiS).

Cholisin. (2007). Dasar-dasar Ilmu Politik. Yogyakarta:UNY Press.

Budimansyah, Dasim, dkk. (2002). Studi Eksperimental Pengembangan Model Pembelajaran. Bandung.

Ennis. Robert. H. (1996). Critical Thinking. Upper Saddle River. New York: Prentice-Hall.

Fajar, A. (2004). Portofolio dalam Pembelajaran IPS. Bandung: Remaja Rosda Karya.

Gunawan, Adi W. (2003). Genius Learning Strategy Petunjuk Praktis untuk Menerapkan Accelarated Learning. Jakarta. Gramedia Pustaka Utama.

Harsanto, Radno. (2005). Melatih Anak Berpikir Analitis,Kritis, dan Kreatif. Jakarta : PT Gramedia Widiasarana Indonesia.

Juha, Mervat Amin. (2010). Thinking Skills Critical Thinking- 2 Chapter. Zaid .IQ.

Myers. (1996) D.G. Social Psychology. Boston: McGraw-Hill College.

Undang-Undang Republik Indonesia Nomor 20 Tahun 2003. Tentang Sistem Pendidikan Nasional.

Winataputra,Udin Saripudin. (2012). Pendidikan Kewarganegaraan Dalam Perspektif Pendidikan untuk mencerdaskan kehidupan Bangsa (Gagasan, instrumentasi, dan praksis).Bandung :Widya Aksara Press. 